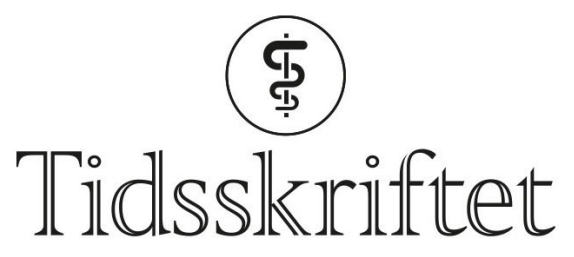

DEN NORSKE LEGEFORENING

\title{
Forside nr. 6/2020
}

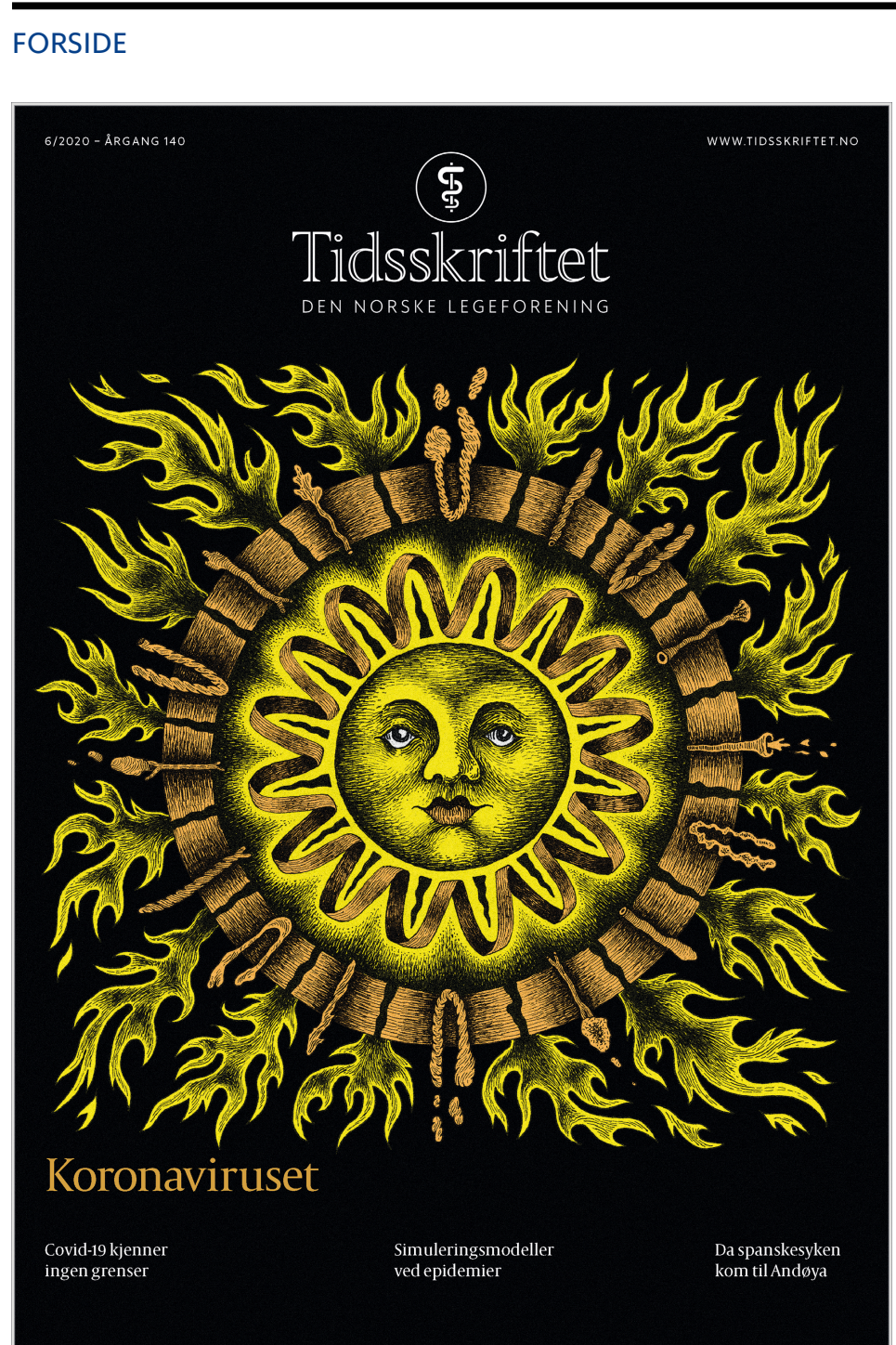

Illustrasjon (C) Tord Torpe

Koronaviruset har forandret samfunnet og hverdagen, også i Tidsskriftet. Vi er ydmyke overfor rollen vi har som formidlingsplattform for kunnskap om covid-19. Fra hjemmekontorer rundt omkring forsøker vi å få manuskripter om viruset raskt ferdig, samtidig som vi erkjenner at alle andre sykdommer ikke tar pause selv om vi har en pågående pandemi.

Forsiden er tegnet av Tord Torpe. Han sier: «Når eg kikar på mikroskopbilete av koronaviruset, minner det meg om barneteikningar av sola. Koronaviruset hentar då også namnet sitt frå sola sin korona. Koronaen er strålekransen ein finn ytst i atmosfæren til sola og andre stjerner. For oss menneske er sjølvsagt sola fyrst og fremst kjelda til alt liv, slik me 
kjenner det. Men det som gjev liv, kan også ta liv.»

Mer av hans arbeider finner du her: www.tordtorpe.com

Publisert: 20. april 2020. Tidsskr Nor Legeforen. DOI: 10.4045/tidsskr.20.06.02

(O) Tidsskrift for Den norske legeforening 2020. Lastet ned fra tidsskriftet.no 